\title{
Gene therapy strategies for hepatocellular carcinoma
}

\author{
Lih-Hwa Hwang \\ Hepatitis Research Center, National Taiwan University Hospital and Graduate Institute of Microbiology, \\ National Taiwan University College of Medicine, 7, Chung-Shan S. Road, Taipei, 10016, Taiwan, R.O.C
}

Received 16 January 2006; accepted 23 March 2006

(c) 2006 National Science Council, Taipei

Key words: antiangiogenic factor, apoptotic gene, gene therapy, hepatocellular carcinoma, immunotherapy, oncolytic virus, siRNA, suicide gene

\section{Summary}

Hepatocellular carcinoma (HCC) is one of the most frequent cancers worldwide. Effective therapy to this cancer is currently lacking, creating an urgent need for new therapeutic strategies for HCC. Gene therapy approach that relies on the transduction of cells with genetic materials, such as apoptotic genes, suicide genes, genes coding for antiangiogenic factors or immunomodulatory molecules, small interfering RNA (siRNA), or oncolytic viral vectors, may provide a promising strategy. The aforementioned strategies have been largely evaluated in the animal models with HCC or liver metastasis. Due to the diversity of vectors and therapeutic genes, being used alone or in combination, gene therapy approach may generate great beneficial effects to control the growth of tumors within the liver.

\section{Introduction}

Hepatocellular carcinoma (HCC) is one of the most common malignancies worldwide. The annual number of mortalities from HCC worldwide is estimated at $1,250,000[1,2]$. In about $90 \%$ of cases, this malignant tumor develops on a background of chronic hepatitis and/or cirrhosis [3]. Liver transplantation, which allows the treatment of both tumor pathology and liver deregulation, is now considered as the most effective therapeutic strategy; however, it is not applicable universally because of the shortage of organ donations and the occurrence of relapse. The strategy is now only limited to patients exhibiting small-size nodules [4]. Large tumors are removed by surgical resection, which is associated with high risk of relapse and does not treat intrinsic hepatic deregulation [5]. Other locoregional therapies, e.g., percutaneous ethanol injection [6] or transcatheter arterial

*To whom correspondence should be addressed. Fax: + 886-223825962; E-mail: lihhwa@ha.mc.ntu.edu.tw embolization [7], are mainly performed with palliative intent; whereas conventional chemotherapy or radiotherapy is ineffective for HCC [8-10]. The survival rate after the onset of symptoms is generally low, creating an urgent need for new therapeutic strategies for HCC.

Gene therapy represents a new and promising therapeutic strategy that relies on the transfer of genetic material into cells in order to generate a beneficial effect against the diseases. To facilitate cell transduction, the genetic material is packaged into vectors that can be of viral [11] and non-viral nature [12]. Gene therapy has been used for many cancers using different strategies. Retroviral or adenoviral (Ad) vectors are the most commonly used for the treatment of HCC. Other non-viral vectors are also used in some studies. Detailed information regarding the vectors used for gene therapy has recently been reviewed by Verma and Weitzman [11]. This review only focuses on the strategies that have been tested to eradicate HCC and liver-related metastases in animal models. The following gene therapy strategies will be discussed: 
oncolytic virus, apoptosis-mediated cell death, genetic prodrug activation, inhibition of angiogenesis, siRNA-targeted gene silencing, and genetic immunotherapy (see summary in Table 1). Notably, some of the gene therapy strategies have entered phase I or II clinical trials as shown in Table 2 .

\section{Oncolytic viruses}

Viruses have been used in the past as potential therapeutic. A large variety of agents have been tested, including rabies, adenovirus, paramyxovirus, Newcastle disease virus and mump virus [13].
Although "responses" have ever been documented, little has emerged from such trials because of the lack of antitumor efficacy repeated in other human trials of that day $[14,15]$. Recent advance in tumor biology, genetics, and virology, e.g., the characterization of the selectivity of reovirus for cells with an activated Ras signaling pathway [16, 17], have allowed for a re-examination of oncolytic virus as a tool of an effective cancer therapy. The conception and development of replicating, oncolytic viral vector alone or in combination with therapeutic transgene delivery, chemotherapy, or radiotherapy, has been an attractive field of study $[18,19]$, and has ultimately led to the transition of these novel therapeutics into the clinic.

Table 1. Summary of the gene therapy strategies used for the treatment of HCC.

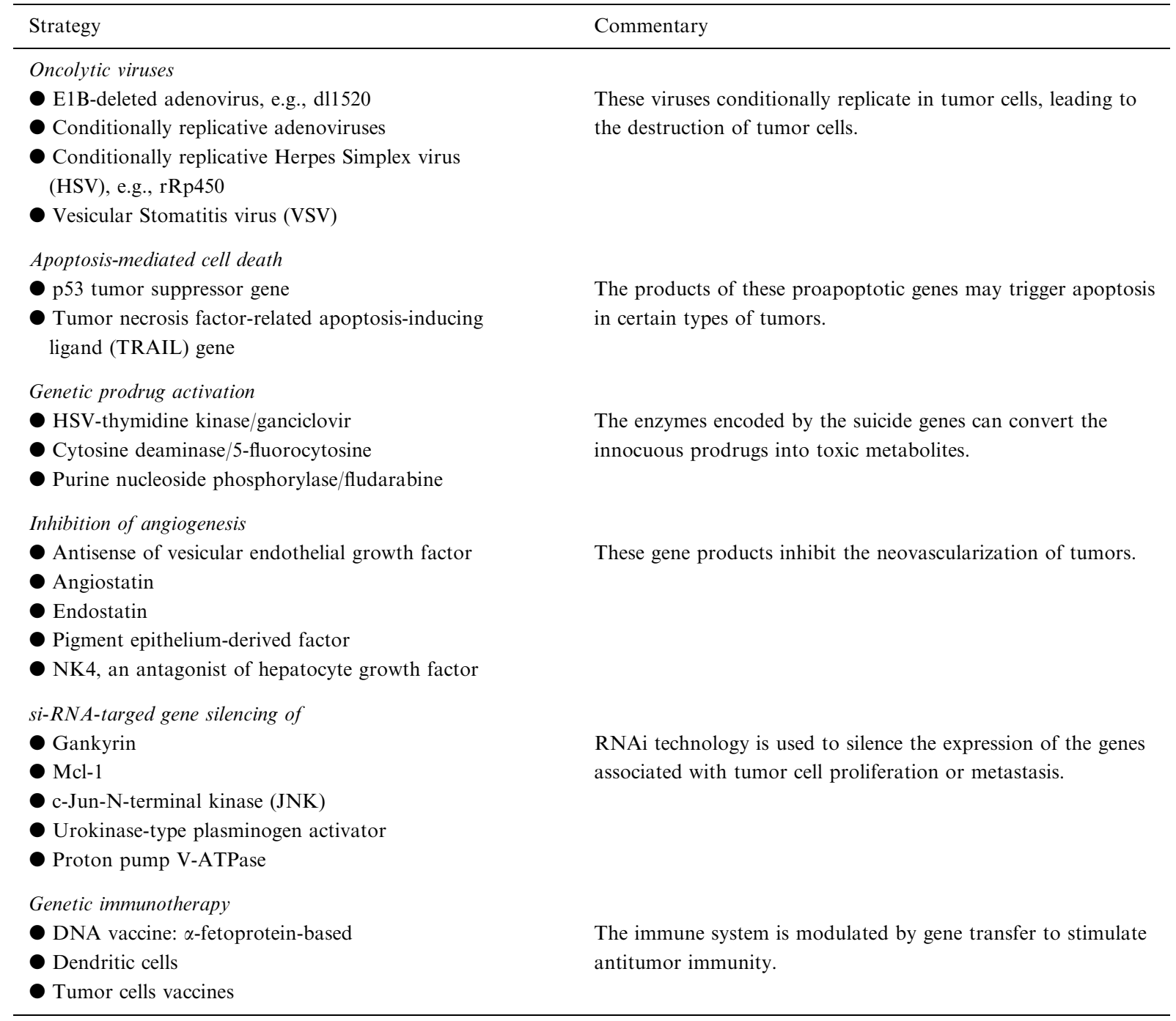


Table 2. Representative gene therapy clinical trials for the treatment of $\mathrm{HCC}$ or liver tumors.

\begin{tabular}{|c|c|c|c|c|c|c|}
\hline No. & Tumor & Gene & Vector & Administration route & Phase & Country \\
\hline 1 & $\mathrm{HCC}$ & & d11520 Ad & Percutaneous & I & UK \\
\hline 2 & $\mathrm{HCC}$ & $\mathrm{p} 53$ & Ad & Intratumoral & I & USA \\
\hline 3 & $\mathrm{HCC}$ & $\mathrm{p} 53$ & Plasmid DNA & Intratumoral & II & Egypt \\
\hline 4 & Liver cancer & Nitroreductase & Ad & Intratumoral & I & UK \\
\hline 5 & Liver cancer & $\begin{array}{l}\text { Prodrug enzyme } \\
\text { CYP2B1 }\end{array}$ & HSV rRp450 & Intrahepatic artery & I & USA \\
\hline 6 & $\mathrm{HCC}$ & $\mathrm{AFP}+\mathrm{GM}-\mathrm{CSF}$ & $\begin{array}{l}\text { Plasmid } \\
\text { DNA + Ad }\end{array}$ & Intradermal & $\mathrm{I} / \mathrm{II}$ & USA \\
\hline 7 & Liver cancer & AFP & Ad & Intravenous & $\mathrm{I} / \mathrm{II}$ & USA \\
\hline 8 & Liver cancer & IL-12 & $\mathrm{Ad}$ & Intratumoral & I & USA \\
\hline 9 & $\begin{array}{l}\text { HCC, pancreatic and } \\
\text { colorectal cancer }\end{array}$ & IL-12 & Ad & Intratumoral & I & Spain \\
\hline 10 & $\begin{array}{l}\mathrm{HCC} \text { and pancreatic } \\
\text { tumor }\end{array}$ & $\mathrm{HSV}-t k$ & Ad & Intratumoral & I & Spain \\
\hline 11 & $\begin{array}{l}\text { Liver metastasis of } \\
\text { colorectal cancer }\end{array}$ & IFN- $\beta$ & Ad & Intravenous & $\mathrm{I} / \mathrm{II}$ & USA \\
\hline 12 & $\begin{array}{l}\text { Liver metastasis of } \\
\text { colorectal cancer }\end{array}$ & IL-12 + HSV-tk & Ad & Intratumoral & I & USA \\
\hline 13 & $\begin{array}{l}\text { Liver metastasis of } \\
\text { colorectal cancer }\end{array}$ & $\begin{array}{l}\text { CC49-Zeta T cell } \\
\text { receptor }\end{array}$ & Retrovirus & Intraheptic artery & $\mathrm{I} / \mathrm{II}$ & USA \\
\hline 14 & Liver metastasis & HSV- $t k$ & Ad & Intratumoral & I & USA \\
\hline 15 & Liver metastasis & $\mathrm{CD}$ & Ad & Intratumoral & I & USA \\
\hline 16 & Liver metastasis & $\mathrm{p} 53$ & Ad & Intrahepatic & II & Switzerland \\
\hline 17 & Liver metastasis & $\mathrm{p} 53$ & Ad & Intrahepatic & I & USA \\
\hline 18 & Digestive tumors & IL-12 & Ad & Intratumoral & I & Spain \\
\hline
\end{tabular}

The data were obtained from the website of "Gene Therapy Clinical Trials Worldwide" (http://www.82.182.180.141/trials).

Oncolytic viruses can mediate the destruction of tumor cells by several potential mechanisms [20]. First, the virus itself is capable of directly lysing the cells as a result of viral replication. The cycle can then repeat itself with progeny virion infecting adjacent cells and destroying them by replication. Second, certain oncolytic viruses generate proteins during their replicative cycle that are directly toxic to the tumor cells. Adenovirus, for example, expresses the E3 $11.6 \mathrm{kDa}$ death protein and the E4ORF protein which are toxic to cells $[21,22]$. Third, oncolytic virus infection may induce non-specific and specific antitumor immunity, leading to tumor destruction. For example, infection of tumor cells by a replicating adenovirus with E1A expression sensitized the tumor cells to tumor necrosis factor (TNF)-mediated killing [23]. Infection of tumor cells by oncolytic virus also led to the induction of cytotoxic T lymphocyte (CTL) responses against viral antigens, which, by an unknown mechanism, also acquired specificity for tumor antigens [24]. Fourth, oncolytic virus can engender an increased sensitivity of tumor cells to chemotherapy and radiotherapy. Synergistic antitumor effects of combining adenovirus infection and cisplatin or 5-fluorouracil (FU) in patients with head and neck cancer have been reported [25]. Fifth, antineoplastic genes can be inserted into the genome of oncolytic virus, offering a concomitant amplification of the transgene expression, which produces an amplified antitumor effect [26-28].

ONYX-015, an adenovirus in which deletion of the E1B gene makes its replication dependent on the defect of the p53 pathway in the infected cells $[29,30]$, has been tested in a p53-null HCC model, Hep3B [31]. The adenovirus caused cytopathic effects of Hep3B in vitro and significantly retarded the growth of Hep3B xenografts in vivo. The antitumor effect was augmented by the addition of cisplatin. Notably, ONYX-015 had no effect on the in vivo growth of the p53-wt HepG2 cells. In addition to the naturally occurring oncolytic 
adenovirus, tumor-specific promoters have been used to express E1A gene, thus achieving tumorselective adenoviral replication. Obviously, the alpha-fetoprotein (AFP) promoter is one of the best choices for HCC. CV890 [32] and Av1E1a04i [33] were the two examples that used AFP promoter to express the E1 gene. The viruses replicated efficiently in human AFP-expressing HCC cell lines, but not in non-AFP-producing cell lines. Single administration of the oncolytic adenovirus into pre-established tumors resulted in significant tumor regression. Moreover, combination of CV890 with doxorubicin revealed synergistic antitumor efficacy [32].

The retinoblastoma tumor suppressor protein $(\mathrm{Rb})$ pathway is dysregulated in a majority of human cancers, in which the E2F promoter activity has been shown selectively activated [34]. Similarly, telomerase reverse transcriptase (TERT) is an unique tumor cell characteristic that is absent in normal cells [35]. Thus, E2F-1 promoter [36] and TERT promoter [37] have been used to drive E1A gene expression, limiting the adenoviral replication in the tumors defective in $\mathrm{Rb}$-pathway (e.g., Hep3B cells) or in the TERT-positive tumor cells, respectively. Strong antitumor effects have been demonstrated in both studies in a xenograft model of HCC.

In addition to adenovirus, a conditionally replicative herpes simplex virus (HSV), rRp450, that is defective in the expression of the large subunit of viral ribonucleotide reductase but expresses the rat cytochrome P450 2B1 transgene, a suicide gene, has also been tested in HCC [38]. The rationale of using $\mathrm{rRp} 450$ is that the mutant preferentially replicates in dividing cells rather than quiescent cells, thus selectively destructing the tumor cells. Moreover, expression of cytochrome P450 rendered the virus-mediated oncolysis ever more severe in the presence of cyclophosphamide, the prodrug for cytochrome P450.

Vesicular stomatitis virus (VSV) is a nonpathogenic RNA virus that is extremely sensitive to the action of interferon (IFN) in normal cells but not in cancer cells [39]. It has been postulated that this finding is due to the fact that IFNresponsive antiviral pathways are defective in many types of tumors [39], including HCC [40]. As a result, VSV has been utilized for the treatment of multifocal liver metastases of colorectal tumor [41] or HCC [42]. The data showed that VSV was able to replicate and induce extensive necrosis in liver tumors but not in normal liver cells. Significant prolongation of survival in the treated animals as compared to the control animals was observed.

In pilot clinical trials, the ONYX-015 adenovirus has proved to be safe when injected intratumorally or intravenously to patient with primary and secondary liver tumors [43]. Intra-hepatic artery injection of this virus to patients with colorectal metastasis to the liver, followed by a 5-FU chemotherapy also showed to be safe [44].

\section{Apoptosis-mediated cell death}

p53 tumor suppressor has been regarded as a guardian of cell cycle progression. Upon DNA damage, it induces DNA repair system and causes cell cycle arrest. It also induces cells to undergo apoptosis when the DNA damage is un-repairable. p53 function is frequently altered in many solid tumors, leading to tumorigenesis or chemoresistance [45]. Accordingly, p53 gene therapy has been proposed for cancers with inactive p53 function.

The status of p53 function in HCC is controversial considering that $80 \%$ of HCCs virtually do not exhibit p53 mutation [46]. However, transfer of wild-type $\mathrm{p} 53$ gene has been extensively tested in HCC regardless of their p53 status. In vitro, overexpression of wild-type p53 in some HCC cell lines has been shown to induce cell apoptosis [47] or inhibit cell growth [48]. Intra-tumoral injection of Ad-p53 in a subcutaneously inoculated HCC [49] or repeated intra-arterial injection of Ad-p53 in an orthotopically implanted rat HCC model [50] was shown to inhibit tumor growth. On the other hand, in the transgenic animas that develop HCC spontaneously transfer of p53 gene did not exert a therapeutic effect in this model [51]. In Hep3B cell line which has both p53 and Rb defectiveness, transduction of p53 gene alone also failed to induce growth arrest [52], suggesting that the ability of a cancer cell to undergo p53-mediated cell growth arrest may depend on the retention of functional downstream effector pathways. As a result, overexpression of p53 gene alone may not be sufficient to eradicate tumors in many cases.

Combination of p53 gene with other proapoptotic genes such as p16 or p27 may offer an alternative opportunity. Sandig et al. have dem- 
onstrated that simultaneous transduction of p53 and p16 genes led to a synergistic antitumor effect in subcutaneously implanted tumors in mice [53]. Combination of p53 gene therapy with conventional chemotherapy or radiotherapy also enhanced the antitumor effect, as shown by $\mathrm{Xu}$ et al. who demonstrated that the transduction of p53 gene into Hep3B cells significantly sensitized the cells to cisplatin [46]. Unfortunately, for such an approach to completely eradicate the tumor, significantly better gene therapy vectors may be needed to modify and trigger apoptosis in most malignant cells in any given tumor, which is far beyond the capabilities of current vectors. In an early clinical trial, intratumoral injection of naked DNA coding for p53 gene in patients with HCC was proven to be safe. Yet, conflicting therapeutic results were observed [54].

In contrast to p53 that requires to be transduced into tumor cells to trigger cell apoptosis or growth arrest, the tumor necrosis factor-related apoptosis-inducing ligand (TRAIL) protein can trigger apoptosis in both membrane-bound and soluble forms, negating the need of transducing the apoptotic gene into every single cell. More importantly, TRAIL induces apoptosis in tumor cells but not in most normal cells in vivo $[55,56]$. Intratumoral administration of the TRAIL vector by electroporation significantly inhibited the growth not only of the HCC directly administered TRAIL vector, but also of distant subcutaneous HCC, with only small and transient liver damage being observed [57]. More interestingly, Ma et al. recently demonstrated that adeno-associated virus (AAV) vector expressing the extracellular domain of TRAIL fused with a signal peptide could be administered orally or intraperitoneally, resulting in long-term and high level expression of soluble TRAIL in vivo, effective regression of the subcutaneously implanted tumors, and lack of toxicity to normal hepatocytes [58]. It will be interesting to further test whether such systemic administration of TRAIL exerts similar tumoricidal effects on orthotopic liver tumors. However, it is to be noted that tumor cells expressing TRAIL receptors are not always sensitive to TRAIL-mediated apoptosis $[59,60]$. The cell sensitivity to TRAIL may be determined by the TRAIL receptor expression as well as the presence of different intracellular mediators [60]. Nevertheless, combination of TRAIL with chemotherapeutic agents has been shown to be able to augment the therapeutic potential [59].

\section{Genetic prodrug activation}

Conventional antiproliferation drugs usually have toxicity both in malignant and non-malignant cells. Therefore, in order to effect a reduction in tumor burdens, the patient's normal tissues and organs have to be exposed to potentially harmful quantities of the drugs. Molecular chemotherapy is designed to circumvent this limitation by selectively transducing the tumor cells with any genes (i.e., suicide genes) that render them sensitive to prodrugs innocuous to non-transduced cells. The most common molecular chemotherapy system utilized to date is the herpes simplex virus thymidine kinase (HSV-tk) gene given in combination with the prodrug ganciclovir (GCV) [61]. The selectivity of the HSV-tk system is that, in contrast to normal mammalian thymidine kinase, HSV-tk preferentially monophosphorylates GCV. The GCV is then further phosporylated by cellular kinase to produce triphosphates that can be incorporated into cellular DNA, thus inhibiting DNA synthesis and leading to cell death [62]. A striking feature of this strategy is the so-called "bystander" effect, whereby the eradication of HSV- $t k$ transduced cells elicits a killing effect on the surrounding non-transduced cells, and potentiating the antitumor activity. The by-stander effect is caused probably by the diffusion of the toxic metabolites to non-transduced neighboring cells $[63,64]$ and also possibly by stimulating antitumoral immune responses with the dying tumor cells $[65,66]$.

A variety of studies have shown the efficacy of the HSV-tk/GCV system for the treatment of experimental HCC. Retroviral vector that transduces only dividing cells was demonstrated to express the HSV-tk gene only in the subcutaneously implanted HCC and cause tumor destruction upon GCV administration [67]. This strategy, however, required repeated injection of the viral vector in order to promote an efficient therapeutic impact. The cured animals exhibited protective immunity against wild-type HCC tumors, suggesting the induction of a by-stander antitumor immunity [67]. Ad-HSV-tk has also been delivered via intraportal route into the animals with chem- 
ically induced HCC [68] or colorectal liver metastasis [69]. The efficacy of the HSV-tk/GCV system was validated in these studies; however, severe liver dysfunction and high mortality upon GCV administration in the animals were also observed. So, in contrast to the common assumption that the cytotoxic metabolites mainly incorporate into tumoral dividing cells, normally non-mitotic tissues, too, can be affected by the HSV-tk/GCV system. Later experiments confirmed that the phosphorylated GCV could be incorporated into both nuclear and mitochondrial DNA, causing mitochondrial dysfunction and toxicity in normal non-dividing cells [70]. To prevent this side effect, intratumoral injection [67] or use of tumor-specific promoters, such as that from AFP [71], to restrict $\mathrm{HSV}-t k$ gene expression to tumor tissue is strongly recommended. A clinical trial has shown that intratumoral injection of an adenovirus coding for HSV- $t k$ into liver metastasis from colorectal cancer followed by systemic GCV treatment was a safe therapy [72].

Other suicide gene/prodrug systems have also been described. The Escherichia coli (E. coli) cytosine deaminase (CD), which promotes the production of toxic 5-fluorouracil (5-FU) from 5-fluorocytosine (5-FC), has been claimed to exert lower hepato-toxicity and stronger by-stander effects as compared to the HSV-tk/GCV system [73]. Intratumoral injection of Ad-CD to the animals subcutaneously inoculated with HCC [74] or intravenous injection of the virus to the animals with liver metastasis of colorectal tumor [75], followed by systemic administration of 5-FC resulted in significant tumor regression. The E. coli purine nucleoside phosphorylase (PNP) converts purine analogs, e.g., fludarabine, into highly toxic metabolites that inhibit RNA, protein, and DNA synthesis. The released metabolites may diffuse across lipid membrane and reach by-stander cells without the requirement of cell-to-cell contact for their antitumor effects [76]. So, PNP/fludarabine combination also exhibited higher by-stander effects in the treatment of HCC tumor as compared to the HSV-tk/GCV system [77]. Though efficient, the metabolites from the PNP/fludarabine system are toxic to both dividing and nondividing cells and can diffuse freely. Thus, it is of great concern about the toxicity of the metabolites to the neighboring normal liver cells when used in clinic.

\section{Inhibition of angiogenesis}

Experimental and clinical studies have shown that primary tumors as well as metastases can remain dormant due to a balance between proliferation and apoptosis unless the angiogenesis is switched on [78]. The growth of endothelial cells is tightly controlled by both positive and negative regulators. The onset of tumor angiogenesis, required for the rapid growth of solid tumors and tumor metastases, is likely to be triggered by an upregulation of angiogenic factors such as basic fibroblast growth factor (bFGF) or vesicular endothelial growth factor (VEGF), or by a down-regulation of antiangiogenic factors such as angiostatin, endostatin, or thrombospondin [78]. Thus, the reconstitution of antiangiogenic factors and/or the removal of angiogenic factors constitute plausible therapeutic strategies to suppress tumor angiogenesis [79]. Antiangiogenesisbased therapy is a universal strategy since the endothelial cells do not vary from one tumor type to the other, further emphasizing the clinical relevance of such an antitumor approach.

$\mathrm{HCC}$ is a hypervascular cancer, so it can be an interesting target for antiangiogenic gene therapy. Expression of the antisense-VEGF cDNA, which down-regulated the endogenous VEGF expression in SK-HEP 1 hepatoma cells, has been shown to inhibit tumor growth in vivo [80]. Another strategy is to use angiogenic inhibitors such as angiostatin, the first four kringle domains of plasminogen, or endostatin, the C-terminal fragment of collagen XVIII. It has been shown that systemic injection of adenovirus encoding angiostatin or endostatin could regress the pre-established subcutaneous HCC, with angiostatin being more effective than endostatin [81]. Further, intraportal injection of AAV encoding angiostatin into the animals with tumors established in the liver also resulted in significant inhibition of neovessels and extensive apoptosis of tumors [82].

Pigment epithelium-derived factor (PEDF) is a recently identified antiangiogenic factor that was first discovered in 1989 by Tombran-Tink as a neurotrophic serpin secreted by retinal pigment epithelial cells [83, 84]. PEDF inhibits angiogenesis in a dose-dependent manner in vitro and in vivo [85, 86] and the antiangiogenic efficiency is thought to be more potent than that of angiostatin, thrombospondin-1 or endostatin [87]. PEDF is found 
throughout the body and is highly expressed in the normal liver [88, 89]; however, it is drastically decreased in patients with cirrhosis or HCC complicated by cirrhosis [90]. In this regard, gene therapy with PEDF gene has been performed for $\mathrm{HCC}$ recently. It was shown that intratumoral injection of a PEDF-expressing plasmid [90] or intravenous injection of Ad-PEDF [91] significantly inhibited the pre-established HCC growth in athymic mice. The antitumor effect was related to a decrease in density of microvessels in tumors. NK4, a hepatocyte growth factor (HGF) antagonist, is another antiangiogenic factor that has been demonstrated to exhibit antitumor activity in many tumors, too [92-95]. NK4 consists of the Nterminal hairpin domain and the four subsequent kringle domain of HGF. Since the HGF-cMET signaling has been reported to promote $\mathrm{HCC}$ development and progression, NK4, by competitively binding to cMET, can inhibit the multiple biological activities of HGF. Besides, NK4 also has antiangiogenic activity through its kringle domain structure [96]. As a result, NK4 can suppress the proliferation of both tumor and endothelial cells. Transfer of NK4 gene into HCC resulted in the inhibition of cell proliferation and migration upon exposure to HGF. The secreted NK4 from the transduced HCC exerted by-stander effect that reduced the migration of non-transduced tumor cells and the proliferation of endothelial cells. AdNK4 delivered in vivo caused significant tumor growth delay in athymic mice [97].

A phase III clinical trial has demonstrated that use of an antiangiogenic drug bevacizumab, a recombinant monoclonal antibody against VEGF, in combination with conventional chemotherapy resulted in improved survival of patients with metastatic colorectal cancer [98, 99]. The encouraging results suggest that antiangiogenic strategy holds great potential for treating liver tumors. However, the multitude of proangiogenic and antiangiogenic factors that can be produced by tumors suggests that inhibition of angiogenesis may require combined action of more than one antiangiogenic factor [100]. The notion was supported by recent observations that attempts to antagonize one factor in the process of tumor angiogenesis can be offset by up-regulation of other proangiogenic factors [101, 102]. It was further proved by a study showing that the treatment efficacy of rat Morris hepatoma cells that secret high levels of VEGF was low with either soluble VEGF receptor (sFlt-1) ( 9 folds) or endostatin (4 folds) monotherapy, but was synergistically increased with endostatin/sFlt-1 combination therapy (77 folds) [103]. Therefore, combination therapy simultaneously addressing two or more angiogenic targets should prove useful in the future.

\section{siRNA-targeted gene silencing}

Small interfering RNA (siRNA) is a recently discovered technology that can direct specific gene silencing by promoting the degradation of target RNA, the so-called RNA interference (RNAi) $[104,105]$. RNAi can be induced in mammalian cells by introduction of synthetic double-stranded siRNA of $21 \sim 23$ base pair in length or by plasmid and/or viral vector systems that express doublestranded short hairpin RNA (shRNA) that are subsequently processed to siRNA by the cellular machinery $[106,107]$. Given the exquisite specificity and exceptional silencing potency of siRNA, compared to earlier reverse genetic technologies, RNAi is now the preferred technique in functional genomics [108]. Furthermore, RNAi has been intensively studied for therapeutic use, particularly in areas of infectious disease and cancer.

Most cancers are characterized by abnormal gene expression, which is thought to contribute to the pathogenesis and the maintenance of the malignant phenotype. Silencing such gene by siRNA would appear to be a rational approach to the therapy of cancer. Indeed, in vitro and in vivo findings have demonstrated the efficacy of siRNA knockdown of gene messages that are pivotal for tumor cell growth, metastasis, angiogenesis, and chemoresistance, leading to tumor growth suppression [109-114].

A novel oncogene, gankyrin, has been found to be highly expressed in $97 \%$ of HCC [115]. The sequence of gankyrin is identical to the p 28 gene product, a subunit of the regulatory complex of the human 26S proteosome [116]. Overexpression of $\mathrm{p} 28^{\mathrm{GANK}}$ increases the phosphorylation of $\mathrm{pRB}$ and inhibits $\mathrm{p} 16^{\mathrm{INK} 4 \mathrm{a}}$ activity, thus accelerating cell-cycle progression [117]. RNAi technology was used to suppress $\mathrm{p} 28^{\mathrm{GANK}}$ expression in HCC. The results demonstrated that the depletion of $\mathrm{p} 28^{\mathrm{GANK}}$ led to the decrease of $\mathrm{pRB}$ 
phosphorylation, the enhancement of caspase 8and 9-mediated apoptosis, and the inhibition of HCC tumor growth in nude mice [118]. RNAi technology has also been used to down-regulate some cellular genes, which then sensitizes the tumor cells to chemotherapy and TRAIL- or CD95-mediated apoptosis. For example, treatment of HCC with siRNA directed against Mcl-1, a member of the Bcl-2 family, led to an elevated caspase 3 activity in Hep3B cells and significantly enhanced the susceptibility of the cells to chemotherapy- or TRAIL-mediated apoptosis [119]. Similarly, siRNA-mediated down-regulation of c-Jun-N-terminal-kinase (JNK) expression, which has been implicated in the survival signaling, strongly enhanced the CD95-mediated apoptosis in HepG2 hepatoma cells, but not in Huh-7 or Hep3B cells [120].

RNAi technology can be used to target the molecules involved in tumor metastasis, too. The serine protease urokinase-type plasminogen activator (u-PA), which plays a pivotal role in the invasiveness of cancer, is up-regulated in human HCC [121, 122]. Using RNAi technology, Salvi et al. have shown that down-regulation of the u-PA expression in SKHep1C3 cells led to a reduction of the migration, invasion, and proliferation of the HCC cells [123]. The increased glycolysis and proton secretion in tumors is also proposed to contribute to the proliferation and invasion of cancer cells during the process of tumorigenesis and metastasis. Proton pump V-ATPase is the enzyme that can pump protons into extracellular environment and is important in solid tumors for maintaining neutral cytosolic $\mathrm{pH}$ and acidic extracellular pH of cancer cells [124]. V-ATPase is expressed in the plasma membrane of some tumors with high metastatic potential. Thus, it has been shown that inhibition of V-ATPase activity by down-regulation of ATP6L, the $16 \mathrm{kDa}$ subunit of proton pump V-ATPase, using RNAi technique effectively retarded cancer growth and suppressed cancer metastasis through the mechanisms of decreasing the proton extrusion and down-regulating the gelatinase activity [125].

Although great potency of RNAi technology to silence gene expression has been shown in vitro, the in vivo usage of this approach is still limited due to the incapability of current vectors to deliver the siRNA to most of tumor cells, a shortcoming that is similar to that of p53-mediated gene therapy.

\section{Genetic immunotherapy}

The immune system is a promising tool for cancer therapy due to the range of effector mechanisms possessed by a diversity of immune cell types and its ability to exert effects with exquisite specificity. Most of tumor cells express tumor-associated antigens (TAAs), which can be used to discriminate tumor cells from normal cells. However, due to the immunological tolerance or ignorance to TAAs, tumor cells still can escape from immune surveillance and grow unlimitedly in the body. With the increased understanding of immune responses, immunotherapeutic strategies now can be used to mobilize or manipulate the immune system of a patient for therapeutic benefit. In this regard, numerous gene therapy approaches for the therapeutic vaccination of individuals who have cancer have been developed, including the use of DNA vaccine [126], dendritic cells (DCs) [127], and autologous or allogenic tumor cells (which are often modified to express various cytokines or co-stimulatory molecules) [128].

\section{DNA vaccine}

AFP is one of the major targets studied by many groups to elicit TAA-specific immune responses to HCC. It is a HCC-specific tumor-associated selfantigen and is the predominant serum protein produced during early development of the liver. In contrast, AFP expression in healthy individuals or patients with benign diseases is very low. Serum AFP levels fall $10^{5}-10^{6}$-fold from $3-5 \mathrm{mg} / \mathrm{ml}$ in the fetal period to $5-10 \mathrm{ng} / \mathrm{ml}$ in adolescents and full adults. However, in HCC patients AFP is frequently re-expressed at high levels. Therefore, it may be a target for immunotherapy of HCC.

It is usually difficult to elicit immunity to self-antigens because of immune tolerance or ignorance. As a result, DNA vaccination with AFP-expressing plasmid alone only induced weak antitumor immunity which, however, was augmented by co-expression of cytokine genes (e.g., IL-12, GM-CSF, or IL-18) [129]. The antitumor immunity could be further enhanced by a primeboost approach that first primed the animals by co-administration of DNA encoding AFP and mouse GM-CSF, followed by boosting the animals with AFP-expressing non-replicating adenoviral vector [130]. Certain proteins that have been 
reported previously to be able to enhance the immunogenecity of tumor antigens, such as heat shock protein [131], HSV-VP22 tegument protein [132], and calreticulin [133], can be considered to conjugate with AFP to generate more potent vaccines in the future.

\section{Dendritic cells}

To be more effective in eliciting the tumor-specific immune responses, the manipulation of professional antigen presenting cells (APC) such as DCs to activate TAA-specific T-cell immunity is an alternative and promising strategy. Ex vivo modification of both human and mouse DCs with gene encoding tumor antigens, including self-antigens, has been shown to effectively stimulate T-cell response in vitro and in various murine models, with induction of long-term immunity against tumor expressing the corresponding antigens [127]. As such, subcutaneous administration of DCs that had been transduced with AFP gene elicited potent AFP-specific CTL responses and protective immunity against the AFP-expressing tumor cells [134]. As an alternative, the DCs pulsed with total tumor lysates without knowing the specific TAAs have also been demonstrated to induce HCC-specific antitumor immunity upon intravenous administration, albeit the antitumor activity was more effective on small tumors than on large tumors [135]. Co-administration of IL-12 with the lysate-pulsed DCs further increased the antitumor effects of DCs, and the CTL activity induced in the animals treated with the combination strategy was much stronger than that in the animals only treated with the lysate-pulsed DCs [136]. Though effective in several animal models, the effectiveness of DCs is generally restricted to early stages of tumors or protection against tumor challenge [137].

\section{Tumor cell vaccines}

Instead of directly manipulating the DCs, some people have engineered tumor cells to express immunomodulatory molecules that can activate DCs locally. CD40 ligand (CD40L) is normally expressed on activated $\mathrm{T}$-cells and binds to CD40 present on the surface of DCs. CD40-CD40L interaction plays a crucial role in the activation of APC and in the initiation of immune response
[138]. Intratumoral injection of Ad-CD40L produced a strong antitumor effect in an orthotopic rat HCC model [139]. The anitumor activity was mainly mediated by $\mathrm{CD} 8+\mathrm{T}$-cells and was associated with increased interleukin (IL)-12 serum levels and enhanced natural killer (NK) cell activity. Flt3 ligand is another cytokine important for the development of DCs and NK cells [140]. Intratumoral injection of adenovirus encoding the extracellular domain of Flt3L produced strong immunogenic activity that resulted in significant tumor regression. The antitumor immunity was mediated by $\mathrm{CD} 3+\mathrm{CD} 4+\mathrm{T}$-cells and NK cells [141].

In addition, the cytokines present in the tumor micromilieu can also affect the stimulation and maturation of innate immune cells, which affect innate immune cell activity. It has been shown that local production of optimal doses of cytokine with gene therapy approaches could induce more efficient therapeutic immune responses than systemic administration of large doses, and would prevent serious adverse effects arising from the systemic administration of these molecules. Numerous cytokines (IL-2, IL-7, IL-12, IL-15, IL-18, IL-21, IL-23, IFN- $\gamma$, IFN- $\alpha$, TNF- $\alpha$, and GM-CSF) have been used in diverse tumor cells [128]. For HCC, some of the cytokines have been tested and shown of great potency. Injection of adenovirus encoding IL-12 through intratumoral or intrahepatic artery route into rats with orthotopic HCC caused significant tumor regression [142]. In this model, NK cell activation and antiangiogenesis were the major mechanisms involved in antitumor responses. Similar strategy also worked successfully on a hepatic metastasis model of colorectal tumor in mice [143]. Combination of IL-12 and costimulatory molecules such as B7.1 has been shown to enhance the antitumor effects. Intratratumoral injection of adenoviruses, producing IL-12 and co-stimulatory molecule B7.1, into a mouse model with subcutaneously implanted HCC model [144] or into a woodchuck model that develops liver tumors spontaneously [145] resulted in strong antitumor effects. In our laboratory we have employed intratumoral injection method to deliver adenovirus encoding GM-CSF or encoding both GM-CSF and endostatin to the rats with orthotopic HCC. Synergistic antitumor efficacy was observed in the combined gene therapy group as compared to the monotherapy group [146]. 
More interestingly, expression of endostatin enhanced the CTL responses against tumor cells and did not interfere with the infiltration of tumorspecific lymphocytes into tumor region. IL-12 or GM-CSF gene therapy has also been used in combination with the HSV-tk/GCV treatment to potentiate the antitumor effect [147]. All these results suggest that combination of immunotherapy with other gene therapy strategies may be more advantageous than being used alone.

\section{Conclusion}

Gene therapy strategies focusing on the treatment of HCC have been investigated for more than 10 years. Within this period, numerous strategies and vectors have been developed to promote the elimination of tumor cells. However, while impressive power of gene therapy at eliminating solid tumors in animal models has been documented, relevant therapeutic results in human are still absent. The sharp contrast stresses the needs of understanding more about the factors that limit the effects of gene therapy tool in human patients. Several aspects may need to be taken into consideration. First, the site of tumor implanted in the animal model may affect the interpretation of antitumor effect. Many studies have used subcutaneous HCC models to evaluate the antitumor effects of therapeutic genes. Our previous results have demonstrated that tumor implanted subcutaneously differed immunologically from those occurring within the liver, and might have different responses to subcutaneous immunotherapy [148, 149]. Thus, the successful generation of antitumor activity against subcutaneous tumors does not necessarily indicate the same efficacy against orthotopic tumors. In this regard, an orthotopic HCC model or a tumor model in a more complex context such as virally or chemically induced HCC is the preferred experimental setting for analyzing the antitumor effects of the therapeutic genes, especially of the immunotherapeutic genes. In addition, considering that most of the $\mathrm{HCC}$ arise from cirrhosis, the animal HCC model complicated with cirrhosis may be more clinically relevant. Second, the duration of transgene expression may influence the antitumor activity. Many studies have used adenoviral vectors to deliver the therapeutic genes, which often resulted in poor infection in malignant cells and short duration of transgene expression, thus reducing the therapeutic efficacy. In the future, efforts should be directed to increase transduction efficiency and to prolong transgene expression. Tumor-selective replicating viruses may help to improve transduction efficiency and to amplify therapeutic gene expression after intratumoral injection of the vector. Alternatively, transduction of the neighboring normal cells with a lentiviral vector or an AAV vector may produce persistent expression, which, however, should be regulable for safety reasons. Third, the variable nature of tumor cells may promote the generation of escape mutants. Most tumor cells mutate with high frequency, so gene therapy with single modality may not be adequate enough to eliminate all the tumor cells. It is strongly envisaged that the combination of transgenes of interest or the combination of gene therapy with conventional therapeutic approaches will greatly improve the treatment of HCC. Similarly, the antitumor activity of oncolytic virus approach may further be enhanced by arming these vectors with therapeutic genes or optimally combining with the conventional chemotherapy or radiation therapy.

In summary, gene therapy is a very plastic procedure in which a diversity of therapeutic genes, vectors, regulatory sequences, and routes of vector administration can be used alone or in combination. It is envisaged that gene therapy will represent a powerful strategy or, in some cases, as a synergistic treatment to conventional therapy, to control tumor growth within the liver.

\section{Acknowledgements}

Research in our laboratory is supported by grant from the National Research Program for Genomic Medicine, National Science Council of the Republic of China.

\section{References}

1. Schafer D.F. and Sorrell M.F., Hepatocellular carcinoma. Lancet 353: 1253-1257, 1999.

2. Yu M.C., Yuan J.M., Govindarajan S. and Ross R.K., Epidemiology of hepatocellular carcinoma. Can. J. Gastroenterol. 14: 703-709, 2000.

3. Colombo M., Hepatocellular carcinoma. J. Hepatol. 15: 225-236, 1992. 
4. Mazzaferro V., Regalia E., Doci R., Andreola S., Pulvirenti A., Bozzetti F., Montalto F., Ammatuna M., Morabito A. and Gennari L., Liver transplantation for the treatment of small hepatocellular carcinomas in patients with cirrhosis. N. Engl. J. Med. 334: 693-699, 1996.

5. Gozzetti G., Belli L., Capussotti L., Di Carlo V., Gennari L., Faccioli A.M., Mazziotti A. and Spina P., Liver resection for hepatocellular carcinoma in cirrhotic patients. Ital. J. Gastroenterol. 24: 105-110, 1992.

6. Livraghi T., Giorgio A., Marin G., Salmi A., de Sio I., Bolondi L., Pompili M., Brunello F., Lazzaroni S., Torzilli G. et al, Hepatocellular carcinoma and cirrhosis in 746 patients: long-term results of percutaneous ethanol injection. Radiology 197: 101-108, 1995.

7. Pelletier G., Ducreux M., Gay F., Luboinski M., Hagege H., Dao T., Van Steenbergen W., Buffet C., Rougier P., Adler M., Pignon J.P. and Roche A., Treatment of unresectable hepatocellular carcinoma with lipiodol chemoembolization: a multicenter randomized trial. Groupe CHC. J. Hepatol. 29: 129-134, 1998.

8. Farmer D.G. and Busuttil R.W., The role of multimodal therapy in the treatment of hepatocellular carcinoma. Cancer 73: 2669-2670, 1994.

9. Levin B. and Amos C., Therapy of unresectable hepatocellular carcinoma. N. Engl. J. Med. 332: 1294-1296, 1995.

10. Venook A.P., Treatment of hepatocellular carcinoma: too many options? J. Clin. Oncol. 12: 1323-1334, 1994.

11. Verma I.M. and Weitzman M.D., Gene therapy: twentyfirst century medicine. Annu. Rev. Biochem. 74: 711-738, 2005

12. Niidome T. and Huang L., Gene therapy progress and prospects: nonviral vectors. Gene Ther. 9: 1647-1652, 2002.

13. Sinkovics J. and Horvath J., New developments in the virus therapy of cancer: a historical review. Intervirology 36: 193-214, 1993.

14. Newman W. and Southam C.M., Virus treatment in advanced cancer; a pathological study of fifty-seven cases. Cancer 7: 106-118, 1954.

15. Cassel W.A. and Garrett R.E., Newcastle disease virus as an antineoplastic agent. Cancer 18: 863-868, 1965.

16. Strong J.E., Coffey M.C., Tang D., Sabinin P. and Lee P.W., The molecular basis of viral oncolysis: usurpation of the Ras signaling pathway by reovirus. EMBO J. 17: 3351-3362, 1998

17. Strong J.E. and Lee P.W., The v-erbB oncogene confers enhanced cellular susceptibility to reovirus infection. $\mathbf{J}$. Virol. 70: 612-616, 1996.

18. O'Shea C.C., Viruses - seeking and destroying the tumor program. Oncogene 24: 7640-7655, 2005.

19. Parato K.A., Senger D., Forsyth P.A. and Bell J.C., Recent progress in the battle between oncolytic viruses and tumours. Nat. Rev. Cancer 5: 965-976, 2005.

20. Mullen J.T. and Tanabe K.K., Viral oncolysis. Oncologist 7: 106-119, 2002

21. Tollefson A.E., Ryerse J.S., Scaria A., Hermiston T.W. and Wold W.S., The E3-11.6-kDa adenovirus death protein (ADP) is required for efficient cell death: characterization of cells infected with adp mutants. Virology 220 152-162, 1996.

22. Shtrichman R. and Kleinberger T., Adenovirus type 5 E4 open reading frame 4 protein induces apoptosis in transformed cells. J. Virol. 72: 2975-2982, 1998.
23. Gooding L.R., Regulation of TNF-mediated cell death and inflammation by human adenoviruses. Infect. Agents Dis. 3: 106-115, 1994

24. Toda M., Rabkin S.D., Kojima H. and Martuza R.L., Herpes simplex virus as an in situ cancer vaccine for the induction of specific anti-tumor immunity. Hum. Gene Ther. 10: 385-393, 1999.

25. Khuri F.R., Nemunaitis J., Ganly I., Arseneau J., Tannock I.F., Romel L., Gore M., Ironside J., MacDougall R.H., Heise C., Randlev B., Gillenwater A.M., Bruso P., Kaye S.B., Hong W.K. and Kirn D.H., A controlled trial of intratumoral ONYX-015, a selectively-replicating adenovirus, in combination with cisplatin and 5-fluorouracil in patients with recurrent head and neck cancer. Nat. Med. 6: 879-885, 2000.

26. Wildner O., Blaese R.M. and Morris J.C., Therapy of colon cancer with oncolytic adenovirus is enhanced by the addition of herpes simplex virus-thymidine kinase. Cancer Res. 59: 410-413, 1999.

27. Andreansky S., He B., van Cott J., McGhee J., Markert J.M., Gillespie G.Y., Roizman B. and Whitley R.J., Treatment of intracranial gliomas in immunocompetent mice using herpes simplex viruses that express murine interleukins. Gene Ther. 5: 121-130, 1998.

28. Parker J.N., Gillespie G.Y., Love C.E., Randall S., Whitley R.J. and Markert J.M., Engineered herpes simplex virus expressing IL-12 in the treatment of experimental murine brain tumors. Proc. Natl. Acad. Sci. USA 97: 2208-2213, 2000.

29. Bischoff J.R., Kirn D.H., Williams A., Heise C., Horn S., Muna M., Ng L., Nye J.A., Sampson-Johannes A., Fattaey A. and McCormick F., An adenovirus mutant that replicates selectively in p53-deficient human tumor cells. Science 274: 373-376, 1996

30. Heise C., Sampson-Johannes A., Williams A., McCormick F., Von Hoff D.D. and Kirn D.H., ONYX-015, an E1B gene-attenuated adenovirus, causes tumor-specific cytolysis and antitumoral efficacy that can be augmented by standard chemotherapeutic agents. Nat. Med. 3: 639-645, 1997.

31. Vollmer C.M., Ribas A., Butterfield L.H., Dissette V.B., Andrews K.J., Eilber F.C., Montejo L.D., Chen A.Y., Hu B., Glaspy J.A., McBride W.H. and Economou J.S., p53 selective and nonselective replication of an E1B-deleted adenovirus in hepatocellular carcinoma. Cancer Res. 59: 4369-4374, 1999.

32. Li Y., Yu D.C., Chen Y., Amin P., Zhang H., Nguyen N. and Henderson D.R., A hepatocellular carcinoma-specific adenovirus variant, CV890, eliminates distant human liver tumors in combination with doxorubicin. Cancer Res. 61: 6428-6436, 2001.

33. Hallenbeck P.L., Chang Y.N., Hay C., Golightly D., Stewart D., Lin J., Phipps S. and Chiang Y.L., A novel tumor-specific replication-restricted adenoviral vector for gene therapy of hepatocellular carcinoma. Hum. Gene Ther. 10: 1721-1733, 1999.

34. Adams P.D. and Kaelin W.G. Jr., Transcriptional control by E2F. Semin. Cancer Biol. 6: 99-108, 1995.

35. Ito H., Kyo S., Kanaya T., Takakura M., Koshida K., Namiki M. and Inoue M., Detection of human telomerase reverse transcriptase messenger RNA in voided urine samples as a useful diagnostic tool for bladder cancer. Clin. Cancer Res. 4: 2807-2810, 1998.

36. Jakubczak J.L., Ryan P., Gorziglia M., Clarke L., Hawkins L.K., Hay C., Huang Y., Kaloss M., Marinov A., 
Phipps S., Pinkstaff A., Shirley P., Skripchenko Y., Stewart D., Forry-Schaudies S. and Hallenbeck P.L., An oncolytic adenovirus selective for retinoblastoma tumor suppressor protein pathway-defective tumors: dependence on E1A, the E2F-1 promoter, and viral replication for selectivity and efficacy. Cancer Res. 63: 1490-1499, 2003.

37. Huang T.G., Savontaus M.J., Shinozaki K., Sauter B.V. and Woo S.L., Telomerase-dependent oncolytic adenovirus for cancer treatment. Gene Ther. 10: 1241-1247, 2003.

38. Pawlik T.M., Nakamura H., Yoon S.S., Mullen J.T., Chandrasekhar S., Chiocca E.A. and Tanabe K.K., Oncolysis of diffuse hepatocellular carcinoma by intravascular administration of a replication-competent, genetically engineered herpesvirus. Cancer Res. 60: 2790-2795, 2000 .

39. Stojdl D.F., Lichty B., Knowles S., Marius R., Atkins H., Sonenberg N. and Bell J.C., Exploiting tumor-specific defects in the interferon pathway with a previously unknown oncolytic virus. Nat. Med. 6: 821-825, 2000.

40. Keskinen P., Nyqvist M., Sareneva T., Pirhonen J., Melen K. and Julkunen I., Impaired antiviral response in human hepatoma cells. Virology 263: 364-375, 1999.

41. Shinozaki K., Ebert O. and Woo S.L., Treatment of multifocal colorectal carcinoma metastatic to the liver of immune-competent and syngeneic rats by hepatic artery infusion of oncolytic vesicular stomatitis virus. Int. J. Cancer 114: 659-664, 2005.

42. Shinozaki K., Ebert O. and Woo S.L., Eradication of advanced hepatocellular carcinoma in rats via repeated hepatic arterial infusions of recombinant VSV. Hepatology 41: 196-203, 2005.

43. Habib N.A., Sarraf C.E., Mitry R.R., Havlik R., Nicholls J., Kelly M., Vernon C.C., Gueret-Wardle D., El-Masry R., Salama H., Ahmed R., Michail N., Edward E. and Jensen S.L., E1B-deleted adenovirus (d11520) gene therapy for patients with primary and secondary liver tumors. Hum. Gene Ther. 12: 219-226, 2001.

44. Reid T., Galanis E., Abbruzzese J., Sze D., Wein L.M., Andrews J., Randlev B., Heise C., Uprichard M., Hatfield M., Rome L., Rubin J. and Kirn D., Hepatic arterial infusion of a replication-selective oncolytic adenovirus (d11520): phase II viral, immunologic, and clinical endpoints. Cancer Res. 62: 6070-6079, 2002.

45. Ferreira C.G., Tolis C. and Giaccone G., p53 and chemosensitivity. Ann. Oncol. 10: 1011-1021, 1999

46. Hollstein M., Sidransky D., Vogelstein B. and Harris C.C., p53 mutations in human cancers. Science 253: 49-53, 1991.

47. Mitry R.R., Sarraf C.E., Havlik R. and Habib N.A., Detection of adenovirus and initiation of apoptosis in hepatocellular carcinoma cells after Ad-p53 treatment. Hepatology 31: 885-889, 2000.

48. Xu G.W., Sun Z.T., Forrester K., Wang X.W., Coursen J. and Harris C.C., Tissue-specific growth suppression and chemosensitivity promotion in human hepatocellular carcinoma cells by retroviral-mediated transfer of the wildtype p53 gene. Hepatology 24: 1264-1268, 1996.

49. Choi J.Y., Park Y.M., Byun B.H., Kim B.S., Hong E.G., Shin D.Y., Seong Y.R. and Im D.S., Adenovirus-mediated p53 tumor suppressor gene therapy against subcutaneous $\mathrm{HuH7}$ hepatoma cell line nodule of nude mice. J. Korean Med. Sci. 14: 271-276, 1999.

50. Anderson S.C., Johnson D.E., Harris M.P., Engler H., Hancock W., Huang W.M., Wills K.N., Gregory R.J.,
Sutjipto S., Wen S.F., Lofgren S., Shepard H.M. and Maneval D.C., p53 gene therapy in a rat model of hepatocellular carcinoma: intra-arterial delivery of a recombinant adenovirus. Clin. Cancer Res. 4: 16491659, 1998.

51. Bao J.J., Zhang W.W. and Kuo M.T., Adenoviral delivery of recombinant DNA into transgenic mice bearing hepatocellular carcinomas. Hum. Gene Ther. 7: 355-365, 1996.

52. Friedman S.L., Shaulian E., Littlewood T., Resnitzky D. and Oren M., Resistance to p53-mediated growth arrest and apoptosis in Hep 3B hepatoma cells. Oncogene 15: 63-70, 1997.

53. Sandig V., Brand K., Herwig S., Lukas J., Bartek J. and Strauss M., Adenovirally transferred p16INK4/CDKN2 and p53 genes cooperate to induce apoptotic tumor cell death. Nat. Med. 3: 313-319, 1997.

54. Habib N.A., Mitry R.R. and Sadri R., p53 and gene therapy for hepatocellular carcinoma. Adv. Exp. Med. Biol. 451: 499-504, 1998.

55. Ashkenazi A., Pai R.C., Fong S., Leung S., Lawrence D.A., Marsters S.A., Blackie C., Chang L., McMurtrey A.E., Hebert A., DeForge L., Koumenis I.L., Lewis D., Harris L., Bussiere J., Koeppen H., Shahrokh Z. and Schwall R.H., Safety and antitumor activity of recombinant soluble Apo2 ligand. J. Clin. Invest. 104: 155-162, 1999.

56. Walczak H., Miller R.E., Ariail K., Gliniak B., Griffith T.S., Kubin M., Chin W., Jones J., Woodward A., Le T., Smith C., Smolak P., Goodwin R.G., Rauch C.T., Schuh J.C. and Lynch D.H., Tumoricidal activity of tumor necrosis factor-related apoptosis-inducing ligand in vivo. Nat. Med. 5: 157-163, 1999.

57. Yamashita Y., Shimada M., Tanaka S., Okamamoto M., Miyazaki J. and Sugimachi K., Electroporation-mediated tumor necrosis factor-related apoptosis-inducing ligand (TRAIL)/Apo2L gene therapy for hepatocellular carcinoma. Hum. Gene Ther. 13: 275-286, 2002.

58. Ma H., Liu Y., Liu S., Xu R. and Zheng D., Oral adenoassociated virus-sTRAIL gene therapy suppresses human hepatocellular carcinoma growth in mice. Hepatology 42: 1355-1363, 2005.

59. Yamanaka T., Shiraki K., Sugimoto K., Ito T., Fujikawa K., Ito M., Takase K., Moriyama M., Nakano T. and Suzuki A., Chemotherapeutic agents augment TRAIL-induced apoptosis in human hepatocellular carcinoma cell lines. Hepatology 32: 482-490, 2000.

60. Kim Y.S., Schwabe R.F., Qian T., Lemasters J.J. and Brenner D.A., TRAIL-mediated apoptosis requires NFkappaB inhibition and the mitochondrial permeability transition in human hepatoma cells. Hepatology 36: 14981508, 2002.

61. Fillat C., Carrio M., Cascante A. and Sangro B., Suicide gene therapy mediated by the Herpes Simplex virus thymidine kinase gene/Ganciclovir system: fifteen years of application. Curr. Gene Ther. 3: 13-26, 2003.

62. Moolten F.L., Drug sensitivity ("suicide") genes for selective cancer chemotherapy. Cancer Gene Ther. 1: 279-287, 1994.

63. Mesnil M. and Yamasaki H., Bystander effect in herpes simplex virus-thymidine kinase/ganciclovir cancer gene therapy: role of gap-junctional intercellular communication. Cancer Res. 60: 3989-3999, 2000.

64. Bi W.L., Parysek L.M., Warnick R. and Stambrook P.J., In vitro evidence that metabolic cooperation is responsible 
for the bystander effect observed with HSV tk retroviral gene therapy. Hum. Gene Ther. 4: 725-731, 1993.

65. Kianmanesh A.R., Perrin H., Panis Y., Fabre M., Nagy H.J., Houssin D. and Klatzmann D., A "distant" bystander effect of suicide gene therapy: regression of nontransduced tumors together with a distant transduced tumor. Hum. Gene Ther. 8: 1807-1814, 1997.

66. Yamamoto S., Suzuki S., Hoshino A., Akimoto M. and Shimada T., Herpes simplex virus thymidine kinase/ ganciclovir-mediated killing of tumor cell induces tumorspecific cytotoxic T cells in mice. Cancer Gene Ther. 4: 9196, 1997.

67. Kuriyama S., Masui K., Kikukawa M., Sakamoto T., Nakatani T., Nagao S., Yamazaki M., Yoshiji H., Tsujinoue H., Fukui H., Yoshimatsu T. and Ikenaka K., Complete cure of established murine hepatocellular carcinoma is achievable by repeated injections of retroviruses carrying the herpes simplex virus thymidine kinase gene. Gene Ther. 6: 525-533, 1999.

68. Qian C., Idoate M., Bilbao R., Sangro B., Bruna O., Vazquez J. and Prieto J., Gene transfer and therapy with adenoviral vector in rats with diethylnitrosamine-induced hepatocellular carcinoma. Hum. Gene Ther. 8: 349-358, 1997.

69. van der Eb M.M., Cramer S.J., Vergouwe Y., Schagen F.H., van Krieken J.H., van der Eb A.J., Borel Rinkes I.H., van de Velde C.J. and Hoeben R.C., Severe hepatic dysfunction after adenovirus-mediated transfer of the herpes simplex virus thymidine kinase gene and ganciclovir administration. Gene Ther. 5: 451-458, 1998.

70. Herraiz M., Beraza N., Solano A., Sangro B., Montoya J., Qian C., Prieto J. and Bustos M., Liver failure caused by herpes simplex virus thymidine kinase plus ganciclovir therapy is associated with mitochondrial dysfunction and mitochondrial DNA depletion. Hum. Gene Ther. 14: 463472, 2003.

71. Gerolami R., Cardoso J., Lewin M., Bralet M.P., Sa Cunha A., Clement O., Brechot C. and Tran P.L., Evaluation of HSV-tk gene therapy in a rat model of chemically induced hepatocellular carcinoma by intratumoral and intrahepatic artery routes. Cancer Res. 60: 9931001,2000

72. Sung M.W., Yeh H.C., Thung S.N., Schwartz M.E., Mandeli J.P., Chen S.H. and Woo S.L., Intratumoral adenovirus-mediated suicide gene transfer for hepatic metastases from colorectal adenocarcinoma: results of a phase I clinical trial. Mol. Ther. 4: 182-191, 2001.

73. Kuriyama S., Mitoro A., Yamazaki M., Tsujinoue H., Nakatani T., Akahane T., Toyokawa Y., Kojima H., Okamoto S. and Fukui H., Comparison of gene therapy with the herpes simplex virus thymidine kinase gene and the bacterial cytosine deaminase gene for the treatment of hepatocellular carcinoma. Scand. J. Gastroenterol. 34: 1033-1041, 1999.

74. Kanai F., Lan K.H., Shiratori Y., Tanaka T., Ohashi M., Okudaira T., Yoshida Y., Wakimoto H., Hamada H., Nakabayashi H., Tamaoki T. and Omata M., In vivo gene therapy for alpha-fetoprotein-producing hepatocellular carcinoma by adenovirus-mediated transfer of cytosine deaminase gene. Cancer Res. 57: 461-465, 1997.

75. Topf N., Worgall S., Hackett N.R. and Crystal R.G., Regional ,pro-drug' gene therapy: intravenous administration of an adenoviral vector expressing the E. coli cytosine deaminase gene and systemic administration of
5 -fluorocytosine suppresses growth of hepatic metastasis of colon carcinoma. Gene Ther. 5: 507-513, 1998.

76. Hughes B.W., King S.A., Allan P.W., Parker W.B. and Sorscher E.J., Cell to cell contact is not required for bystander cell killing by Escherichia coli purine nucleoside phosphorylase. J. Biol. Chem. 273: 2322-2328, 1998.

77. Mohr L., Shankara S., Yoon S.K., Krohne T.U., Geissler M., Roberts B., Blum H.E. and Wands J.R., Gene therapy of hepatocellular carcinoma in vitro and in vivo in nude mice by adenoviral transfer of the Escherichia coli purine nucleoside phosphorylase gene. Hepatology 31: 606-614, 2000.

78. Hanahan D. and Folkman J., Patterns and emerging mechanisms of the angiogenic switch during tumorigenesis. Cell 86: 353-364, 1996.

79. Kountouras J., Zavos C. and Chatzopoulos D., Apoptotic and anti-angiogenic strategies in liver and gastrointestinal malignancies. J. Surg. Oncol. 90: 249-259, 2005.

80. Kang M.A., Kim K.Y., Seol J.Y., Kim K.C. and Nam M.J., The growth inhibition of hepatoma by gene transfer of antisense vascular endothelial growth factor. J. Gene Med. 2: 289-296, 2000.

81. Schmitz V., Wang L., Barajas M., Gomar C., Prieto J. and Qian C., Treatment of colorectal and hepatocellular carcinomas by adenoviral mediated gene transfer of endostatin and angiostatin-like molecule in mice. Gut 53: 561-567, 2004.

82. Xu R., Sun X., Tse L.Y., Li H., Chan P.C., Xu S., Xiao W., Kung H.F., Krissansen G.W. and Fan S.T., Long-term expression of angiostatin suppresses metastatic liver cancer in mice. Hepatology 37: 1451-1460, 2003.

83. Folkman J. and Shing Y., Angiogenesis. J. Biol. Chem. 267: 10931-10934, 1992.

84. Tombran-Tink J., Chader G.G. and Johnson L.V., PEDF: a pigment epithelium-derived factor with potent neuronal differentiative activity. Exp. Eye Res. 53: 411-414, 1991.

85. Gao G., Li Y., Gee S., Dudley A., Fant J., Crosson C. and Ma J.X., Down-regulation of vascular endothelial growth factor and up-regulation of pigment epithelium-derived factor: a possible mechanism for the anti-angiogenic activity of plasminogen kringle 5. J. Biol. Chem. 277: 9492-9497, 2002.

86. Cao W., Tombran-Tink J., Chen W., Mrazek D., Elias R. and McGinnis J.F., Pigment epithelium-derived factor protects cultured retinal neurons against hydrogen peroxide-induced cell death. J. Neurosci. Res. 57: 789-800, 1999.

87. Houenou L.J., D'Costa A.P., Li L., Turgeon V.L., Enyadike C., Alberdi E. and Becerra S.P., Pigment epithelium-derived factor promotes the survival and differentiation of developing spinal motor neurons. J. Comp. Neurol. 412: 506-514, 1999.

88. Palmieri D., Watson J.M. and Rinehart C.A., Age-related expression of PEDF/EPC-1 in human endometrial stromal fibroblasts: implications for interactive senescence. Exp. Cell Res. 247: 142-147, 1999.

89. Dawson D.W., Volpert O.V., Gillis P., Crawford S.E., $\mathrm{Xu}$ H., Benedict W. and Bouck N.P., Pigment epithelium-derived factor: a potent inhibitor of angiogenesis. Science 285: 245-248, 1999.

90. Matsumoto K., Ishikawa H., Nishimura D., Hamasaki K., Nakao K. and Eguchi K., Antiangiogenic property of pigment epithelium-derived factor in hepatocellular carcinoma. Hepatology 40: 252-259, 2004. 
91. Wang L., Schmitz V., Perez-Mediavilla A., Izal I., Prieto J. and Qian C., Suppression of angiogenesis and tumor growth by adenoviral-mediated gene transfer of pigment epithelium-derived factor. Mol. Ther. 8: 72-79, 2003.

92. Maemondo M., Narumi K., Saijo Y., Usui K., Tahara M., Tazawa R., Hagiwara K., Matsumoto K., Nakamura T. and Nukiwa T., Targeting angiogenesis and HGF function using an adenoviral vector expressing the HGF antagonist NK4 for cancer therapy. Mol. Ther. 5: 177$185,2002$.

93. Hirao S., Yamada Y., Koyama F., Fujimoto H., Takahama Y., Ueno M., Kamada K., Mizuno T., Maemondo M., Nukiwa T., Matsumoto K., Nakamura T. and Nakajima Y., Tumor suppression effect using NK4, a molecule acting as an antagonist of HGF, on human gastric carcinomas. Cancer Gene Ther. 9: 700-707, 2002.

94. Saimura M., Nagai E., Mizumoto K., Maehara N., Okino H., Katano M., Matsumoto K., Nakamura T., Narumi K., Nukiwa T. and Tanaka M., Intraperitoneal injection of adenovirus-mediated NK4 gene suppresses peritoneal dissemination of pancreatic cancer cell line AsPC-1 in nude mice. Cancer Gene Ther. 9: 799-806, 2002

95. Heideman D.A., van Beusechem V.W., Bloemena E., Snijders P.J., Craanen M.E., Offerhaus G.J., Derksen P.W., de Bruin M., Witlox M.A., Molenaar B., Meijer C.J. and Gerritsen W.R., Suppression of tumor growth, invasion and angiogenesis of human gastric cancer by adenovirus-mediated expression of NK4. J. Gene Med. 6: 317-327, 2004.

96. Kuba K., Matsumoto K., Date K., Shimura H., Tanaka M. and Nakamura T., HGF/NK4, a four-kringle antagonist of hepatocyte growth factor, is an angiogenesis inhibitor that suppresses tumor growth and metastasis in mice. Cancer Res. 60: 6737-6743, 2000.

97. Heideman D.A., Overmeer R.M., van Beusechem V.W., Lamers W.H., Hakvoort T.B., Snijders P.J., Craanen M.E., Offerhaus G.J., Meijer C.J. and Gerritsen W.R., Inhibition of angiogenesis and HGF-cMET-elicited malignant processes in human hepatocellular carcinoma cells using adenoviral vector-mediated NK4 gene therapy. Cancer Gene Ther. 12: 954-962, 2005.

98. McCarthy M., Antiangiogenesis drug promising for metastatic colorectal cancer. Lancet 361: 1959, 2003.

99. Hurwitz H., Fehrenbacher L., Novotny W., Cartwright T., Hainsworth J., Heim W., Berlin J., Baron A., Griffing S., Holmgren E., Ferrara N., Fyfe G., Rogers B., Ross R. and Kabbinavar F., Bevacizumab plus irinotecan, fluorouracil, and leucovorin for metastatic colorectal cancer. N. Engl. J. Med. 350: 2335-2342, 2004.

100. Herbst R.S. and Sandler A.B., Non-small cell lung cancer and antiangiogenic therapy: what can be expected of bevacizumab? Oncologist 9(Suppl 1) 19-26, 2004.

101. Kerbel R.S., Yu J., Tran J., Man S., Viloria-Petit A., Klement G., Coomber B.L. and Rak J., Possible mechanisms of acquired resistance to anti-angiogenic drugs: implications for the use of combination therapy approaches. Cancer Metast. Rev. 20: 79-86, 2001.

102. Viloria-Petit A.M. and Kerbel R.S., Acquired resistance to EGFR inhibitors: mechanisms and prevention strategies. Int. J. Radiat. Oncol. Biol. Phys. 58: 914-926, 2004.

103. Graepler F., Verbeek B., Graeter T., Smirnow I., Kong H.L., Schuppan D., Bauer M., Vonthein R., Gregor M. and Lauer U.M., Combined endostatin/sFlt-1 antiangio- genic gene therapy is highly effective in a rat model of HCC. Hepatology 41: 879-886, 2005.

104. Sontheimer E.J. and Carthew R.W., Silence from within: endogenous siRNAs and miRNAs. Cell 122: 9-12, 2005.

105. Zamore P.D. and Haley B., Ribo-gnome: the big world of small RNAs. Science 309: 1519-1524, 2005.

106. Filipowicz W., NAi: the nuts and bolts of the RISC machine. Cell 122: 17-20, 2005.

107. Tang G., siRNA and miRNA: an insight into RISCs. Trends Biochem. Sci. 30: 106-114, 2005.

108. Lu P.Y., Xie F. and Woodle M.C., In vivo application of RNA interference: from functional genomics to therapeutics. Adv. Genet. 54: 117-142, 2005.

109. Gao L., Zhang L., Hu J., Li F., Shao Y., Zhao D., Kalvakolanu D.V., Kopecko D.J., Zhao X. and Xu D.Q., Down-regulation of signal transducer and activator of transcription 3 expression using vector-based small interfering RNAs suppresses growth of human prostate tumor in vivo. Clin. Cancer Res. 11: 6333-6341, 2005.

110. Zhang X., Chen Z.G., Choe M.S., Lin Y., Sun S.Y., Wieand H.S., Shin H.J., Chen A., Khuri F.R. and Shin D.M., Tumor growth inhibition by simultaneously blocking epidermal growth factor receptor and cyclooxygenase2 in a xenograft model. Clin. Cancer Res. 11: 6261-6269, 2005.

111. Saydam O., Glauser D.L., Heid I., Turkeri G., Hilbe M., Jacobs A.H., Ackermann M. and Fraefel C., Herpes simplex virus 1 amplicon vector-mediated siRNA targeting epidermal growth factor receptor inhibits growth of human glioma cells in vivo. Mol. Ther. 12: 803-812, 2005.

112. Chen Z., Varney M.L., Backora M.W., Cowan K., Solheim J.C., Talmadge J.E. and Singh R.K., Downregulation of vascular endothelial cell growth factor-C expression using small interfering RNA vectors in mammary tumors inhibits tumor lymphangiogenesis and spontaneous metastasis and enhances survival. Cancer Res. 65: 9004-9011, 2005.

113. Landen C.N., Kinch M.S. and Sood A.K., EphA2 as a target for ovarian cancer therapy. Expert Opin. Ther. Targets 9: 1179-1187, 2005.

114. Duxbury M.S., Ito H., Benoit E., Zinner M.J., Ashley S.W. and Whang E.E., Retrovirally mediated RNA interference targeting the M2 subunit of ribonucleotide reductase: a novel therapeutic strategy in pancreatic cancer. Surgery 136: 261-269, 2004.

115. Fu X.Y., Wang H.Y., Tan L., Liu S.Q., Cao H.F. and Wu M.C., Overexpression of p28/gankyrin in human hepatocellular carcinoma and its clinical significance. World J. Gastroenterol. 8: 638-643, 2002.

116. Hori T., Kato S., Saeki M., DeMartino G.N., Slaughter C.A., Takeuchi J., Toh-e A. and Tanaka K., cDNA cloning and functional analysis of p28 (Nas6p) and p40.5 (Nas7p), two novel regulatory subunits of the $26 \mathrm{~S}$ proteasome. Gene 216: 113-122, 1998.

117. Li J. and Tsai M.D., Novel insights into the INK4-CDK4/ 6-Rb pathway: counter action of gankyrin against INK4 proteins regulates the CDK4-mediated phosphorylation of Rb. Biochemistry (Mosc). 41: 3977-3983, 2002.

118. Li H., Fu X., Chen Y., Hong Y., Tan Y., Cao H., Wu M. and Wang H., Use of adenovirus-delivered siRNA to target oncoprotein p28GANK in hepatocellular carcinoma. Gastroenterology 128: 2029-2041, 2005.

119. Wirth T., Kuhnel F., Fleischmann-Mundt B., Woller N., Djojosubroto M., Rudolph K.L., Manns M., Zender L. 
and Kubicka S., Telomerase-dependent virotherapy overcomes resistance of hepatocellular carcinomas against chemotherapy and tumor necrosis factor-related apoptosis-inducing ligand by elimination of Mcl-1. Cancer Res. 65: 7393-7402, 2005.

120. Kuntzen C., Sonuc N., De Toni E.N., Opelz C., Mucha S.R., Gerbes A.L. and Eichhorst S.T., Inhibition of c-Jun$\mathrm{N}$-terminal-kinase sensitizes tumor cells to CD95-induced apoptosis and induces G2/M cell cycle arrest. Cancer Res. 65: 6780-6788, 2005.

121. Zhou L., Hayashi Y., Itoh T., Wang W., Rui J. and Itoh H., Expression of urokinase-type plasminogen activator, urokinase-type plasminogen activator receptor, and plasminogen activator inhibitor-1 and -2 in hepatocellular carcinoma. Pathol. Int. 50: 392-397, 2000.

122. Muehlenweg B., Sperl S., Magdolen V., Schmitt M. and Harbeck N., Interference with the urokinase plasminogen activator system: a promising therapy concept for solid tumours. Expert Opin. Biol. Ther. 1: 683-691, 2001.

123. Salvi A., Arici B., De Petro G. and Barlati S., Small interfering RNA urokinase silencing inhibits invasion and migration of human hepatocellular carcinoma cells. Mol. Cancer Ther. 3: 671-678, 2004.

124. Nishi T. and Forgac M., The vacuolar $(\mathrm{H}+)$-ATPases nature's most versatile proton pumps. Nat. Rev. Mol. Cell Biol. 3: 94-103, 2002.

125. Lu X., Qin W., Li J., Tan N., Pan D., Zhang H., Xie L., Yao G., Shu H., Yao M., Wan D., Gu J. and Yang S., The growth and metastasis of human hepatocellular carcinoma xenografts are inhibited by small interfering RNA targeting to the subunit ATP6L of proton pump. Cancer Res. 65: 6843-6849, 2005.

126. Donnelly J.J., Wahren B. and Liu M.A., DNA vaccines: progress and challenges. J. Immunol. 175: 633-639, 2005

127. Banchereau J. and Palucka A.K., Dendritic cells as therapeutic vaccines against cancer. Nat. Rev. Immunol. 5: 296-306, 2005.

128. Mach N. and Dranoff G., Cytokine-secreting tumor cell vaccines. Curr. Opin. Immunol. 12: 571-575, 2000.

129. Grimm C.F., Ortmann D., Mohr L., Michalak S., Krohne T.U., Meckel S., Eisele S., Encke J., Blum H.E. and Geissler M., Mouse alpha-fetoprotein-specific DNAbased immunotherapy of hepatocellular carcinoma leads to tumor regression in mice. Gastroenterology 119: 11041112,2000

130. Meng W.S., Butterfield L.H., Ribas A., Dissette V.B., Heller J.B., Miranda G.A., Glaspy J.A., McBride W.H. and Economou J.S., alpha-Fetoprotein-specific tumor immunity induced by plasmid prime-adenovirus boost genetic vaccination. Cancer Res. 61: 8782-8786, 2001.

131. Hauser H., Shen L., Gu Q.L., Krueger S. and Chen S.Y., Secretory heat-shock protein as a dendritic cell-targeting molecule: a new strategy to enhance the potency of genetic vaccines. Gene Ther. 11: 924-932, 2004.

132. Kim T.W., Hung C.F., Kim J.W., Juang J., Chen P.J., He L., Boyd D.A. and Wu T.C., Vaccination with a DNA vaccine encoding herpes simplex virus type 1 VP22 linked to antigen generates long-term antigen-specific CD8positive memory $\mathrm{T}$ cells and protective immunity. Hum. Gene Ther. 15: 167-177, 2004.

133. Cheng W.F., Hung C.F., Chai C.Y., Hsu K.F., He L., Ling $\mathrm{M}$. and $\mathrm{Wu}$ T.C., Tumor-specific immunity and antiangiogenesis generated by a DNA vaccine encoding calreticulin linked to a tumor antigen. J. Clin. Invest. 108: 669-678, 2001.

134. Vollmer C.M. Jr., Eilber F.C., Butterfield L.H., Ribas A., Dissette V.B., Koh A., Montejo L.D., Lee M.C., Andrews K.J., McBride W.H., Glaspy J.A. and Economou J.S., Alpha-fetoprotein-specific genetic immunotherapy for hepatocellular carcinoma. Cancer Res. 59: 3064-3067, 1999.

135. Lee W.C., Wang H.C., Jeng L.B., Chiang Y.J., Lia C.R., Huang P.F., Chen M.F., Qian S. and Lu L., Effective treatment of small murine hepatocellular carcinoma by dendritic cells. Hepatology 34: 896-905, 2001.

136. Tatsumi T., Takehara T., Kanto T., Miyagi T., Kuzushita N., Sugimoto Y., Jinushi M., Kasahara A., Sasaki Y., Hori M. and Hayashi N., Administration of interleukin12 enhances the therapeutic efficacy of dendritic cellbased tumor vaccines in mouse hepatocellular carcinoma. Cancer Res. 61: 7563-7567, 2001.

137. Ribas A., Butterfield L.H., Glaspy J.A. and Economou J.S., Cancer immunotherapy using gene-modified dendritic cells. Curr. Gene Ther. 2: 57-78, 2002.

138. Grewal I.S. and Flavell R.A., CD40 and CD154 in cellmediated immunity. Annu. Rev. Immunol. 16: 111-135, 1998.

139. Schmitz V., Barajas M., Wang L., Peng D., Duarte M., Prieto J. and Qian C., Adenovirus-mediated CD40 ligand gene therapy in a rat model of orthotopic hepatocellular carcinoma. Hepatology 34: 72-81, 2001.

140. Lyman S.D., James L., Vanden Bos T., de Vries P., Brasel K., Gliniak B., Hollingsworth L.T., Picha K.S., McKenna H.J., Splett R.R. et al, Molecular cloning of a ligand for the flt3/flk-2 tyrosine kinase receptor: a proliferative factor for primitive hematopoietic cells. Cell 75: 1157-1167, 1993.

141. Shaw S.G., Maung A.A., Steptoe R.J., Thomson A.W. and Vujanovic N.L., Expansion of functional NK cells in multiple tissue compartments of mice treated with Flt3ligand: implications for anti-cancer and anti-viral therapy. J. Immunol. 161: 2817-2824, 1998.

142. Barajas M., Mazzolini G., Genove G., Bilbao R., Narvaiza I., Schmitz V., Sangro B., Melero I., Qian C. and Prieto J., Gene therapy of orthotopic hepatocellular carcinoma in rats using adenovirus coding for interleukin 12. Hepatology 33: 52-61, 2001.

143. Pham-Nguyen K.B., Yang W., Saxena R., Thung S.N., Woo S.L. and Chen S.H., Role of NK and T cells in IL-12-induced anti-tumor response against hepatic colon carcinoma. Int. J. Cancer 81: 813-819, 1999.

144. Putzer B.M., Stiewe T., Rodicker F., Schildgen O., Ruhm S., Dirsch O., Fiedler M., Damen U., Tennant B., Scherer C., Graham F.L. and Roggendorf M., Large nontransplanted hepatocellular carcinoma in woodchucks: treatment with adenovirus-mediated delivery of interleukin 12/B7.1 genes. J. Natl. Cancer Inst. 93: 472479, 2001

145. Tatsumi T., Takehara T., Kanto T., Kuzushita N., Ito A., Kasahara A., Sasaki Y., Hori M. and Hayashi N., B7-1 (CD80)-gene transfer combined with interleukin-12 administration elicits protective and therapeutic immunity against mouse hepatocellular carcinoma. Hepatology 30 : 422-429, 1999.

146. Tai K.F., Chen P.J., Chen D.S. and Hwang L.H., Concurrent delivery of GM-CSF and endostatin genes by a single adenoviral vector provides a synergistic effect 
on the treatment of orthotopic liver tumors. J. Gene Med. 5: 386-398, 2003.

147. Drozdzik M., Qian C., Xie X., Peng D., Bilbao R., Mazzolini G. and Prieto J., Combined gene therapy with suicide gene and interleukin-12 is more efficient than therapy with one gene alone in a murine model of hepatocellular carcinoma. J. Hepatol. 32: 279-286, 2000.

148. Tai K.F., Chen D.S. and Hwang L.H., Curative potential of GM-CSF-secreting tumor cell vaccines on established orthotopic liver tumors: mechanisms for the superior antitumor activity of live tumor cell vaccines. J. Biomed. Sci. 11: 228-238, 2004.

149. Chang C.J., Tai K.F., Roffler S. and Hwang L.H., The immunization site of cytokine-secreting tumor cell vaccines influences the trafficking of tumor-specific $\mathrm{T}$ lymphocytes and antitumor efficacy against regional tumors. J. Immunol. 173: 6025-6032, 2004. 